\title{
Wegener's Granulomatosis with Parotid Gland Involvement and Pneumothorax
}

\author{
Yılmaz Bülbül Tevfik Özlü Funda Öztuna \\ Department of Chest Diseases, Medical School, Karadeniz Technical University, Trabzon, Turkey
}

\section{Key Words}

Hemoptysis · Parotid gland · Pneumothorax · Wegener's granulomatosis

\begin{abstract}
Objective: Wegener's granulomatosis is a systemic vasculitis characterized by necrotizing granulomatous lesions mostly involving the upper and lower respiratory tract. The disease rarely causes parotid gland involvement and pneumothorax. We report a case of Wegener's granulomatosis involving parotid gland, and complicated with a pneumothorax. Clinical Presentation: A 45year-old man admitted with a 3-week history of painful left parotid gland enlargement and hemoptysis. On physical examination a painful and hard mass was detected on the left pre-auricular area. Cervical CT revealed a $2 \times 1.5 \mathrm{~cm}$ hypodense lesion mimicking an abscess on the left parotid gland. Chest radiograph and thorax CT demonstrated nodular and cavitating opacities on the right and left upper zones. There were numerous erythrocytes in urine sediment. The drained pus material from the parotid abscess demonstrated only gram-positive cocci (Staphylococcus aureus). Two weeks treatment with teicoplanin resulted in no improvement. Meanwhile, parotid gland biopsy revealed necrotizing granulomatous inflammation. There was a sixfold increase in serum cANCA levels. With the diagnosis of Wegener's
\end{abstract}

granulomatosis, cyclophosphamide and prednisolone were initiated. However, 1 month later, pneumothorax developed as a complication of rupture of a cavitary lesion. Conclusion: Parotid gland swelling may be the initial presenting symptom of Wegener's granulomatosis. It can be confused with infectious or malignant diseases of the gland, and the lung involvement may be complicated with pneumothorax.

Copyright $\odot$ 2003S. Karger AG, Basel

\section{Introduction}

Wegener's granulomatosis is a systemic vasculitis, characterized by necrotizing granulomatous lesions mostly involving the upper and lower respiratory tract. It may afflict all organs, but the nose, paranasal sinuses and lungs are the main sites to be affected. Parotid gland involvement as an initial presentation is unusual and may be confused with other neoplastic and non-neoplastic diseases of the gland [1-6]. Pneumothorax is also a rare complication [7-12]. In this report, we present a case of Wegener's granulomatosis with parotid gland involvement as a major initial manifestation and with pneumothorax as a complication of cavity rupture.

\section{KARGER \\ Fax +4161306 1234 \\ E-Mail karger@karger.ch \\ www.karger.com

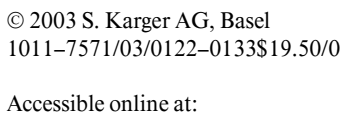

Dr. Y1lmaz Bülbül

KTU Tıp Fakültesi, Göğüs Hastalıkları Anabilim Dalı

61080 Trabzon (Turkey)

Tel. +90 $4623257031 /+904623775468$

E-Mailybulbul@meds.ktu.edu.tr 


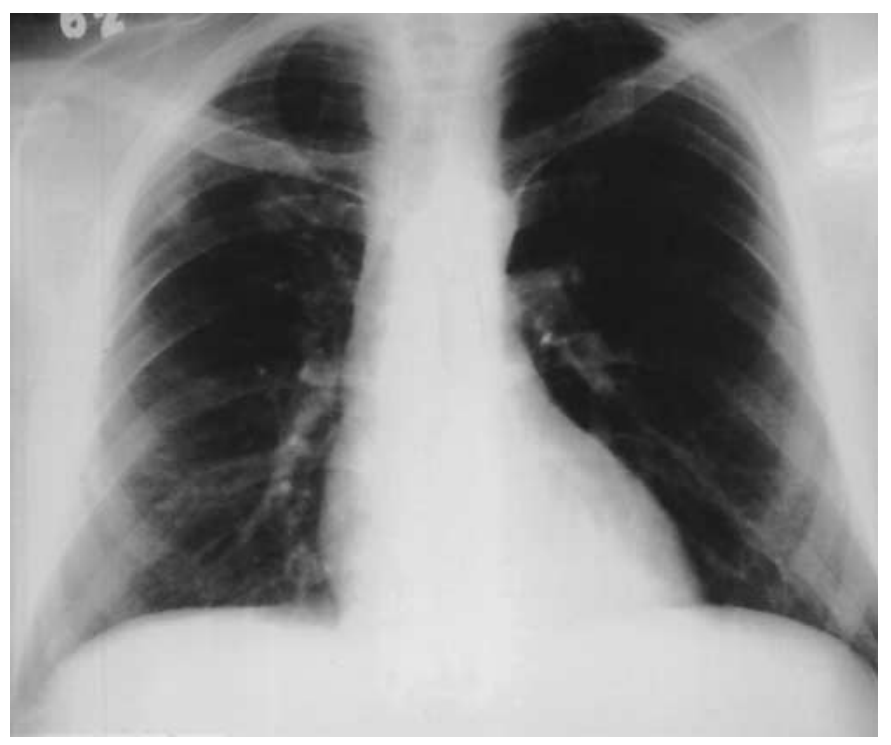

Fig. 1. Chest radiograph: Nodular lesions in the right upper zone.

\section{Case Report}

A male patient, a 45-year-old beekeeper, was admitted with a 3week history of painful left parotid gland enlargement and hemoptysis. He smoked 20 cigarettes per day. On physical examination, a painful and hard mass was detected on the left pre-auricular area. Hematological examination showed that the erythrocyte sedimentation rate was $80 \mathrm{~mm} / \mathrm{h}$, white cell count was $8,900 \mathrm{cells} / \mathrm{mm}^{3}$ and hematocrit was $31.5 \%$. Serum protein and albumin levels were 6.1 and $2.3 \mathrm{~g} / \mathrm{dl}$, respectively, but other blood chemistry values were within normal limits. Viral serologic tests (mumps, Epstein-Barr virus, cytomegalovirus, hepatitis $\mathrm{B}$ and $\mathrm{C}$, and $\mathrm{HIV}$ ) were negative. There were numerous erythrocytes in the urine sediment. In the radiological evaluation, cervical CT revealed a $2 \times 1.5 \mathrm{~cm}$ hypodense lesion mimicking an abscess in the left parotid gland. Chest radiograph and thorax $\mathrm{CT}$ showed nodular and cavitating opacities in the right and left upper zones (fig. 1-3).

With the diagnosis of parotid gland abscess, intravenous ampicillin-sulbactam was instituted and the patient was operated on. At operation, multiple abscesses with pus material were observed in the gland. After the pus material was drained, tissue and pus samples were obtained and examined for specific and non-specific infections (pyogenic, mycotic infections, tuberculosis, etc.). Microscopic examination revealed abundant polymorphonuclear leukocytes and grampositive cocci (Staphylococcus aureus methicillin-resistant) but not other bacteria or fungi. Ampicillin-sulbactam was stopped and intravenous teicoplanin was given in accord with the sensitivity of the microorganism. Two weeks of treatment with teicoplanin showed no recovery. During this period fever sometimes reached $39.2^{\circ} \mathrm{C}$, hemoptysis persisted and $5 \mathrm{~kg}$ weight loss occurred. The parotid mass enlarged and was accompanied with ulceration and exudation. Peripheral facial paralysis developed. Meanwhile, parotid gland biopsy showed mixed inflammatory cell infiltration including polymorphonuclear leukocytes, destroyed gland lobules and necrotizing granulomatous inflammation including multinuclear giant cells and histio- cytes suggesting a granulomatous disease other than tuberculosis. Cytology of a sample taken by CT-guided transthoracic fine needle aspiration (TTFNA) with a 22-gauge needle also showed abscess formation.

Systemic diseases with necrotizing granuloma formation were considered, especially Wegener's granulomatosis. Teicoplanin was stopped and appropriate serologic tests were performed. Immunoglobulin levels (IgA, IgG, IgM) and complement $\mathrm{C}_{4}$ were normal, but complement $\mathrm{C}_{3}$ level was high $(156 \mathrm{mg} / \mathrm{dl})$. Anti-nuclear, antidsDNA, anti-glomerular basement membrane, anti-SS A and antiSS B antibodies were negative, but c-antineutrophil cytoplasmic antibody (cANCA) and rheumatoid factor (RF) were positive. RF was $19.1 \mathrm{IU} / \mathrm{ml}$ (normal $<10 \mathrm{IU} / \mathrm{ml}$ ) and cANCA was $27.0 \mathrm{U} / \mathrm{ml}$ (normal $<4 \mathrm{U} / \mathrm{ml}$ ). cANCA activity was confirmed with an IFA (immunofluorescence antibody) method.

Renal ultrasound and intravenous pyelography were normal. Nasal endoscopy showed masses obliterating both nasal cavities, with septal and conchal perforation. Bronchoscopic examination revealed subglottic narrowing, mucosal changes and crusts. Pulmonary function tests gave results as follows; $\mathrm{FEV}_{1}$ : 2.03 litres $(54 \%$ pred.), FVC: 3.27 litres ( $71 \%$ pred.), $\mathrm{FEV}_{1} / \mathrm{FVC}: 62 \%$, and $\mathrm{FEF}_{25-75}$ : 1.66 litres (39\% pred.).

Six weeks after admission to our hospital, cyclophosphamide and methylprednisolone were started with the diagnosis of Wegener's granulomatosis. However, kidney involvement was not proven by biopsy. Trimethoprim-sulphamethoxazole was also given. One month of treatment was accompanied by a significant improvement. The size of the parotid mass decreased and other complaints (fever, hematuria, hemoptysis, etc.) regressed. In contrast, pulmonary lesions progressed and cavitation occurred (fig. 4). One month after the onset of treatment, a pneumothorax developed on the right side and it could not be expanded despite the introduction of tube thoracostomy (fig. 5). Air leakage and empyema could not be controlled. Intravenous cephoperazone-sulbactam and amikacin were initiated, cyclophosphamide was stopped and prednisolone was tapered. The patient was then referred to another medical center for thoracic surgery. After referral for thoracic surgery the patient was not re-admitted to our hospital. On thoracotomy, pneumothorax, empyema and bronchopleural fistula had been detected, and cavity resection and decortication had been performed. It was learned from the patient's epicrisis and from the responsible physician that, following surgery, immunosuppressive therapy was not restarted because of recurrent respiratory infections. The patient suffered progressive respiratory insufficiency due to these infections, severe cachexia and endobronchial involvement/narrowing as the illness progressed and died 8.5 months after diagnosis.

\section{Discussion}

Wegener's granulomatosis is thought to be an autoimmune disease. There is a strong and specific association between the disease and ANCA. The sensitivity of granular cytoplasmic staining pattern (cANCA) was reported to be $91 \%$ [13] and antibody titers correlate with the clinical activity of the disease [14]. On the other hand, some exogenous factors, especially infectious agents, have also been postulated in the aetiology. Chronic nasal carriage of 

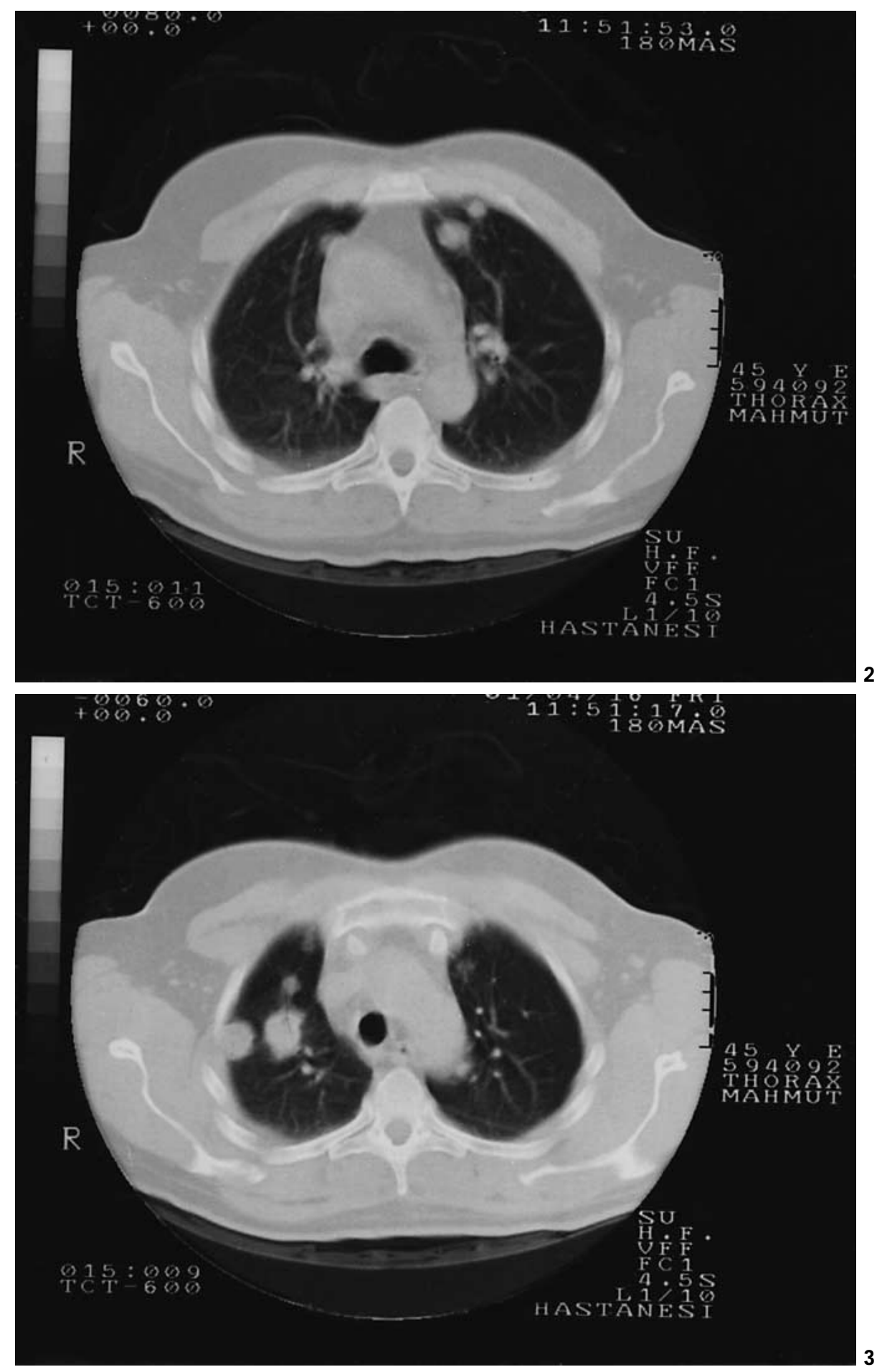

nodular opacities in the upper lobes.

$S$. aureus has been reported to be an independent risk factor for relapse [15]. Stegemann et al. [15] reported that $63 \%$ of 57 patients with Wegener's granulomatosis were chronic nasal carriers of $S$. aureus. The culture of pus from parotid abscess in our case revealed $S$. aureus coloni-

Parotid Involvement and Pneumothorax in Wegener's Granulomatosis zation or infection, which led to initial misdiagnosis. Brons et al. [16] have also suggested that staphylococcal acid phosphatase acts as a planted antigen and initiates glomerulonephritis and vasculitis. Thus, effective therapy directed against this bacterium can be expected to reduce 
4

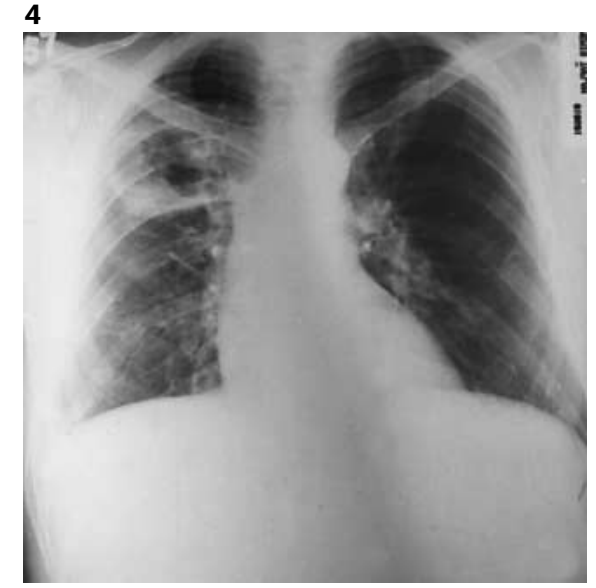

5

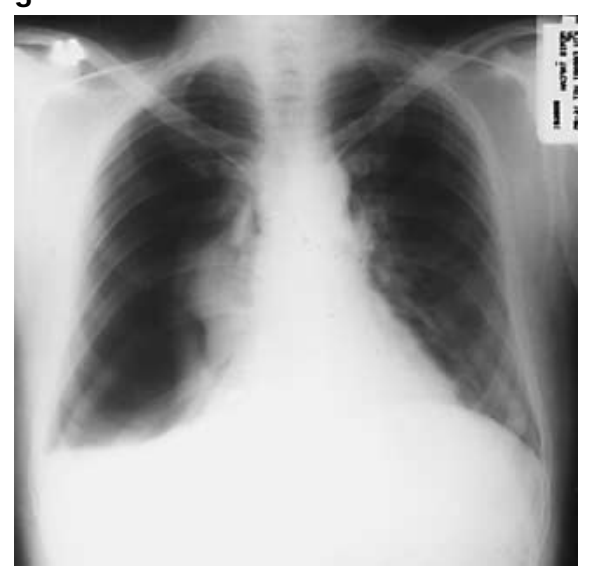

Fig. 4. Enlarging cavitary lesion in the right upper zone.

Fig. 5. Total pneumothorax in the right hemithorax.

the number of relapses. A prospective, randomized and placebo-controlled study has shown that treatment with trimethoprim-sulphamethoxazole significantly reduced the incidence of relapses [17].

Immunosuppressive therapy, mainly using corticosteroids and cyclophosphamide, has been considered essential for the management of Wegener's granulomatosis. This treatment induces remission in more than $90 \%$ of the patients [18]. While untreated Wegener's granulomatosis is usually fatal, survival improved dramatically following the standard cyclophosphamide and corticosteroid therapy. One-, five- and 10-year survivals were reported to be 93,79 and $75 \%$, respectively, by Koldingsnes and Nossent [19] and another study by Reinhold-Keller et al. [20] reported a 10 -year survival rate of $88 \%$ and a median survival of 21.7 years. Even with appropriate therapy, our patient died within the first year following diagnosis. Koldingsnes and Nossent [19] reported that, of 56 patients, $7.1 \%$ died within 1 month of starting treatment; all had multi-organ disease. Our patient had multiple organ involvement. Renal disease or impaired renal function, pulmonary involvement, advanced age, anemia and initial white blood cell count over than $10,000 / \mu 1$ are reported to be bad prognostic factors [19-23].

The disease mostly involves the upper respiratory tract, lung and the kidney. Parotid gland involvement is rare and unusual. It may be the initial symptom of the disease [4, 5]. Many conditions such as infectious diseases (viral, bacterial infections, tuberculosis, fungal infections, etc.) and non-infectious diseases (Sjögren syndrome, sarcoidosis, tumours, etc.) can result in parotid gland enlargement [1-4]. cANCA remains an important diagnostic test for Wegener's granulomatosis, and histological examination confirms the diagnosis.
At the end of the 1-month treatment, rupture of the cavitary lesion in the right lung resulted in total pneumothorax in this patient. Pneumothorax is a rare complication of the disease [7-12] that may be seen as an initial presenting symptom or as a complication of situations such as immunosuppressive treatment or TTFNA [7, 8 12]. The rupture of the cavity, as in our case, may also cause pneumothorax $[9,11]$. The pneumothorax in our case was not expanded despite the introduction of tube thoracostomy. This was probably related to continuation of air leakage due to delayed wound healing and lack of recovery of the ruptured cavity because of accompanying empyema and usage of immunosuppressive agents; cyclophosphamide and corticosteroid [24-26]. Treatment with these agents was tapered off to control infection and improve wound healing.

In conclusion, parotid swelling may be the initial presenting symptom of Wegener's granulomatosis. It can be confused with infectious or malignant diseases of the gland, while lung involvement may be complicated with pneumothorax. 


\section{References}

1 Iko BO, Chinwuba CW, Myers EM, Teal JS: Sarcoidosis of the parotid gland. Br J Radiol 1986;59:547-552.

2 Suleiman AM: Tuberculous parotitis: Report of 3 cases. Br J Oral Maxillofac Sur 2001;39: 320-323.

3 Flaitz CM: Parotitis as the initial sign of juvenile Sjogren's syndrome. Pediatr Dent 2001;23: 140-142.

4 Berge S, Niederhagen B, von Lindern JJ, Appel $\mathrm{T}$, Reich RH: Salivary gland involvement as an initial presentation of Wegener's disease: A case report. Int J Oral Maxillofac Surg 2000;29: 450-452.

5 Benson-Mitchell R, Tolley N, Croft CB, Roberts D: Wegener's granuloma - presenting as a unilateral parotid swelling. J Laryngol Otol 1994; 108:431-432.

6 Lustmann J, Segal N, Markitziu A: Salivary gland involvement in Wegener's granulomatosis: A case report and review of the literature. Oral Surg Oral Med Oral Pathol 1994;77:254259.

7 Epstein DM, Gefter WB, Miller WT, Gohel V, Bonavita JA: Spontaneous pneumothorax: An uncommon manifestation of Wegener granulomatosis. Radiology 1980;135:327-328.

8 Ogawa M, Azemoto R, Makino Y, Mori Y, Ueda S, Wakashin M, Ohto M: Pneumothorax in a patient with Wegener's granulomatosis during treatment with immunosuppressive agents. J Intern Med 1991;229:189-192.

9 Michel J, Courthaliac C, Andre M, Lhoste A, Aumaitre O: Quid? Pneumothorax complicating Wegener disease with rupture of pleura of cavitary nodule (in French). J Radiol 2001;82: 73-75.

10 Jaspan T, Davison AM, Walker WC: Spontaneous pneumothorax in Wegener's granulomatosis. Thorax 1982;37:774-775.
11 Wolffenbuttel BH, Weber RF, Kho GS: Pyopneumothorax: A rare complication of Wegener's granulomatosis. Eur J Respir Dis 1985; 67:223-227.

12 Carruthers DM, Connor S, Howie AJ, Exley AR, Raza K, Bacon PA, Guest P: Percutaneous image-guided biopsy of lung nodules in the assessment of disease activity in Wegener's granulomatosis. Rheumatology 2000;39:776782.

13 Rao JK, Weinberger M, Oddone EZ, Allen NB, Landsman P, Feussner JR: The role of antineutrophil cytoplasmic antibody (c-ANCA) testing in the diagnosis of Wegener granulomatosis: A literature review and meta-analysis. Ann Intern Med 1995; 123:925-932.

14 Cohen Tervaert JW, van der Woude FJ, Fauci AS, Ambrus JL, Velosa J, Keane WF, Meijer S, van der Giessen M, van der Hem GK, The TH, et al: Association between active Wegener's granulomatosis and anticytoplasmic antibodies. Arch Intern Med 1989;149:24612465.

15 Stegeman CA, Tervaert JW, Sluiter WJ, Manson WL, de Jong PE, Kallenberg CGM: Association of chronic nasal carriage of Staphylococcus aureus and higher relapse rates in Wegener granulomatosis. Ann Intern Med 1994; 120:12-17.

16 Brons RH, Bakker HI, Van Wijk RT, Van Dijk NW, Muller Kobold AC, Limburg PC, Manson WL, Kallenberg CG, Cohen Tervaert JW: Staphylococcal acid phosphatase binds to endothelial cells via charge interaction: A pathogenic role in Wegener's granulomatosis? Clin Exp Immunol 2000;119:566-573.

17 Stegeman CA, Tervaert JWC, de Jong PE, Kallenberg CGM: Trimethoprim sulfomethaxazole (co-trimaxazole) for the prevention of relapses of Wegener's granulomatosis. Dutch CoTrimexazole Wegener Study Group. N Engl J Med 1996;335:16-20.
18 Hoffman GS, Kerr GS, Leavitt RY, Hallahan CW, Lebovics RS, Travis WD, Rottem M, Fauci AS: Wegener granulomatosis: An analysis of 158 patients. Ann Intern Med 1992;116: 488-498.

19 Koldingsnes W, Nossent H: Predictors of survival and organ damage in Wegener's granulomatosis. Rheumatology (Oxford) 2002;41: $572-581$.

20 Reinhold-Keller E, Beuge N, Latza U, de Groot K, Rudert H, Nolle B, Heller M, Gross WL: An interdisciplinary approach to the care of patients with Wegener's granulomatosis: Longterm outcome in 155 patients. Arthritis Rheum 2000;43:1021-1032.

21 Fauci AS, Haynes BF, Katz P, Wolff SM: Wegener's granulomatosis: Prospective clinical and therapeutic experience with 85 patients for 21 years. Ann Intern Med 1983;98:76-85.

22 Mahr A, Girard T, Agher R, Guillevin L: Analysis of factors predictive of survival based on 49 patients with systemic Wegener's granulomatosis and prospective follow-up. Rheumatology 2001;40:492-498.

23 Briedigkeit L, Kettritz R, Gobel U, Natusch R: Prognostic factors in Wegener's granulomatosis. Postgrad Med J 1993;69:856-861.

24 Wicke C, Halliday B, Allen D, Roche NS, Scheuenstuhl H, Spencer MM, Roberts AB, Hunt TK: Effects of steroids and retinoids on wound healing. Arch Surg 2000;135:12651270

25 Cohen SC, Gabelnick HL, Johnson RK, Goldin A: Effect of cyclophosphamide and adriamycin on the healing of surgical wounds in mice. Cancer 1975;36:1277-1281.

26 Cerfolio RJ, Bass CS, Pask AH, Katholi CR: Predictors and treatment of persistent air leaks. Ann Thorac Surg 2002;73:1727-1730. 